\title{
Structural Composition of a Corporate Reputation Portfolio (Sustainable Development Perspective)
}

\author{
Ingrida Smaiziene $^{1} \&$ Robertas Jucevicius ${ }^{1}$ \\ ${ }^{1}$ Faculty of Social Sciences, Kaunas University of Technology, Kaunas, Lithuania \\ Correspondence: Ingrida Smaiziene, Faculty of Social Sciences, Kaunas University of Technology, K. \\ Donelaiciost, 20, LT-44239 Kaunas, Lithuania. Tel: 370-37-300-122. E-mail: ingrida.smaiziene@ktu.lt
}

Received: May 6, 2013

Accepted: May 26, 2013

Online Published: July 12, 2013

doi:10.5539/ijbm.v8n15p44

URL: http://dx.doi.org/10.5539/ijbm.v8n15p44

\begin{abstract}
The paper explores corporate reputation as a network of specific reputations associated with a company. A collection of the strategic reputations, selected by the key decision-makers in a company for a systematic management and investments with expectations for future returns to the company, comprises a corporate reputation portfolio.

The paper presents a conceptual explanation of how to create structural composition of a corporate reputation portfolio. On the basis of stakeholder heterogeneity, multiple expectations and corporate sustainability, two groups of the components of the portfolio-co-reputations and sub-reputations-are distinguished and integrated into a framework of a structural composition of a corporate reputation portfolio.
\end{abstract}

Keywords: corporate reputation, corporate reputation portfolio, economic reputation, social reputation, environmental reputation, social responsibility, sustainable development

\section{Introduction}

The main principles of the modern portfolio theory that has been originally developed for managing financial investments are nowadays applied to managing other types of assets as well. A portfolio-based approach is used when discussing brand portfolios, intellectual property portfolios, industrial purchasing portfolios, strategic resource portfolios, company business portfolios, supplier-customer relationship portfolios etc. (Rutkauskas, Lapinskaite-Vvohlfahrt \& Stasytyte, 2011).

Corporate reputation, as a form of intangible assets, might also be treated as an object of a portfolio-based approach. The idea of applying a portfolio-based approach to building reputational capital was presented by Andrikopoulos and Koronis (2007), but it still lacks appropriate consideration both in theoretical, and empirical levels.

As a definition of portfolio refers to some criteria-based collection of the components belonging to the phenomenon discussed, a corporate reputation portfolio might be characterized as a collection of reputational components a company chooses for managing, when expecting future benefits. Although some corporate reputational components are mentioned by a number of researchers (Dollinger, Golden \& Saxton, 1997; Neville, Bell \& Menguc, 2005; Eberl and Schwaiger, 2005; Helm, 2007; Bebbington, Larringa \& Moneva, 2008; Eisenegger, 2009; etc.), in most of the studies, reputational components are discussed fragmentarily attempting to reveal the complexity of the phenomenon rather than investigating how companies choose reputational components for investments and management. There is still a great controversy in this field: there has been no solid agreement towards what reputational components are, what interrelationship exists among them. In different sources of literature, the same issues are treated as the components of reputation, the determinants, or subsequences. Besides, most discussions on reputational components lack theoretical background and are based more on intuitive interpretations than on theory-based reasoning.

The following research questions still have to be answered: what are the components of corporate reputation and how these components of corporate reputation might be integrated into a structural composition of a corporate reputation portfolio?

The paper aims at providing a conceptual explanation of how to create structural composition of a corporate reputation portfolio. The research method applied is systematic analysis of scientific literature in the field of 
reputation management, business strategy and corporate sustainability.

The paper has been structured as follows. In the first part of the paper, a portfolio-based approach and the demand for it in managing corporate reputation is discussed. In the second and third parts, the concepts of co-reputations and sub-reputations as the components of a corporate reputation portfolio are presented and discussed. The framework for a structural composition of a corporate reputation portfolio, integrating co-reputations and sub-reputations, is presented in the fourth part of the paper.

\section{A Portfolio-Based Approach in Managing Corporate Reputation}

A widely accepted approach perceives corporate reputation as a result of assimilation of stakeholders' opinions and attitudes towards a company. However, such a perspective in operationalization corporate reputation gains more and more critics (Kumar, 2008; Smaiziene and Jucevicius, 2010; Walker, 2010). With reference to Kumar (2008), inability to distinguish among various types of reputations was one of the main limitations in exploring corporate reputation as a research object in the past. As a matter of fact, companies invest not in a general reputation, but in some specific types of reputations: reputation for high quality of the products, reputation for honorable dealings with business partners, etc. (Kumar, 2008).

Nowadays corporate performance is multiform-managing extensive brand portfolios, operating in diverse local and foreign markets, seeking high profitability and, at the same time, demonstrating corporate philanthropy, initiating and supporting local and worldwide social and environmental issues. Stakeholders' values and expectations towards a company are diverse too. That does not allow interpreting the perceptions of a company as an aggregated general opinion and giving a simple label of "bad company" or "good company" to a corporation. This leads to the acknowledgement that a company has not one, but several reputations existing at the same time (Helm, 2007; Walker, 2010). Therefore, corporate reputation should be treated as a network of specific reputations associated with a company.

Despite fragmentary academic attempts to decompose the structure of corporate reputation (Neville et al, 2005; Eberl and Schwaiger, 2005; Eisenegger, 2009), there is still a great controversy in the field of distinguishing reputational components. Corporate reputation components are being singled out on the basis of target markets, stakeholders, diverse performance, corporate characteristics, etc. Most of such attempts have been based on providing a normative theoretical imperative (Andrikopoulos and Koronis, 2007); they lack theoretical background and coherence with strategic decision-making.

Andrikopoulos and Koronis (2007) claim that reputation components should not be acquiesced as an indisputable imperative. Rather, these components should be distinguished and prioritized by company key decision makers, with regard to a corporate strategy. Such an approach to building reputation capital is called $a$ portfolio-based approach (Andrikopoulos and Koronis, 2007) and it considers reputations (or the components of corporate reputation) as intangible assets that companies invest in with the expectations of some benefits in the future.

A portfolio-based reputation management requires the decisions of investing into the components of corporate reputation, made on the assessed risk and expected future benefits, as a modern portfolio theory treats investing as a tradeoff between risk and expected return (Rutkauskas et al., 2011). Strategic reputational components a company chooses for investing its tangible and intangible resources must increase a company's reputational assets and minimize the risk (Andrikopoulos and Koronis, 2007).

A portfolio-based approach enables a company a) to take into consideration the complexity and the multiplicity of the stakeholders (Andrikopoulos and Koronis, 2007), b) to identify the components of corporate reputation in coherence with corporation's mission, vision, strategic goals, and the peculiarities of company business, c) to choose strategic reputational components for investing, d) to allocate resources for shaping and managing different types of reputations more effectively, and e) to choose better techniques for managing the chosen specific reputations rather than attempting to create an overall positive reputation.

It follows that a corporate reputation portfolio represents a collection of specific reputations (also called the components of corporate reputation) that are invested in, measured and managed systematically for maximizing reputation expected returns and minimizing a reputation risk. The creation and proper management of such a portfolio enables to choose an optimal strategy by seeking to maximize performance on corporate reputation capital while maintaining organizational stability and minimizing organizational risk (Andrikopoulos and Koronis, 2007).

In this paper, while discussing a structural composition of a corporate reputation portfolio, two new original terms are proposed to be used for defining the components of corporate reputation and for explaining the 
interrelationship among them, namely, the terms of co-reputations and sub-reputations.

\section{Co-Reputations as the Components of a Corporate Reputation Portfolio}

\subsection{Theoretical Background for Distinguishing Co-Reputations}

Distinguishing diverse reputations on the basis on stakeholder heterogeneity is the most popular way for the exploration of a multidimensional approach to corporate reputation. Most scholars (De Castro, Saez \& Lopez, 2004; Luoma-aho, 2007; Helm, 2007; Neville et al., 2005; Smaiziene and Jucevicius, 2010; Walker, 2010) support the position that an organization's reputation varies among stakeholder groups. Such an attitude has been based on the acknowledgment that stakeholders-consumers, employees, suppliers, retailers, investors, community, stockholders, competitors, etc.-have diverse values, standards, and expectations towards the company, its performance, and results. Consumers expect a high quality of goods and services foremost (Helm, 2007), investors search for high profitability, and environmentalists search for sustainable development (Neville et al., 2005). Reputation among employees is driven mostly by workplace environment; reputation among suppliers is heavily driven by the company product and service quality and by financial performance (Helm, 2007). A company itself has diverse intentions, objectives, and behavior towards different stakeholder groups, and has diverse relations with stakeholder groups.

Such a multiplicity of stakeholders leads to the acknowledgement that a company has not one, but a few reputations existing at the same time. Therefore, the operationalization of the corporate reputation concept should start with introducing the concept of co-reputations. As the prefix co- means together, corporate co-reputations are defined as company's stakeholder-specific reputations, existing together at the same time, but diverse in multiple stakeholder groups.

At least four types of corporate co-reputations might be determined in the context of four main categories of stakeholders, distinguished by Dowling (2002): reputation among customers, reputations in functional, normative and diffused stakeholder groups. In the field of business strategy, rivals are considered to be one the most important stakeholder group that can affect, directly or indirectly, an organization's actions and perceptions in the marketplace. Therefore, reputation among rivals is presented as a part of a corporate reputation portfolio.

\subsection{Reputation in Customer Groups}

As customers are considered to be one of the largest and most important stakeholder groups for most organizations, this type of co-reputation is explored by the majority of scholars and experts: potential risk sources are discussed, guidelines for managing those are proposed, and the benefits of a positive customer-specific reputation are highlighted. The focus on this type of co-reputation is stressed by financial and operational benefits that positive reputation among current and potential customers brings to an organization: reduction of uncertainty considering product quality (Helm, 2007), making customers feel more secure in buying the products and services (Jackson, 2004), adding extra psychological value to a product and service (Dowling, 2002), encouraging greater loyalty (Fombrum, 1996), helping attract the new ones (Dalton and Croft, 2003), premium prices (Jackson, 2004), etc.

With reference to Dowling (2002), consumers often cannot be referred to as a homogeneous group, since different types of customers want different sets of benefits and/or solutions to their problems from an organization. Therefore, this type of co-reputation might be categorized in a number of smaller co-reputations, determined with regard to the multiplicity of geographic, socio-demographic, socio-economic, or psychographic target groups.

\subsection{Reputation in Functional Groups of Stakeholders}

Functional groups of stakeholders directly affect many of the day-to-day activities of an organization (Dowling, 2002). Employees are considered to be an internal functional group; suppliers, distributors, retailers, service providers, etc. are referred to as the external ones.

Employees, as an internal functional stakeholder group, are often called company ambassadors, and the benefits of a positive reputation in this particular stakeholder group have been acknowledged by a number of scholars (Fombrum, 1996; Dowling, 2002) Thus, the advantages are a better access to superior human capital: a reduced uncertainty of recent and future employees with regard to employer characteristics (Cable and Graham, 2000; Helm, 2007), the attraction of better applicants for company job positions (Jackson, 2004), the encouragement of greater loyalty from employees (Fombrum, 1996), positive reviews and records about the company, its products, and actions to other stakeholder groups. However, this co-reputation as an object of management still lacks more comprehensive research and attention in practice. 
A positive reputation in external functional groups, such as suppliers, service providers, retailers, etc., enhances a bargaining power in trade channels, provides better access to professional service (Dowling, 2002), and helps to reinforce interrelationship (Dalton and Croft, 2003).

Regarding the heterogeneity of functional stakeholder groups, this part of a corporate reputation portfolio might be divided into the following co-reputations: reputation among employees, reputation among suppliers, reputation among retailers, and reputation among stockholders.

\subsection{Reputation in Normative Stakeholder Groups}

Referring to Dowling (2002), normative groups of stakeholders provide the authority for an organization to function and set the general rules and regulations, by which activities are carried out. Government departments, regulatory institutions, local councils, trade associations, professional societies, etc. are supposed to be the external groups of normative stakeholders, and stockholders as well as the board of directors are the internal ones (Dowling, 2002). Company's endeavors for shaping the perceptions and attitudes towards a company in normative stakeholder groups are based on such expected benefits, as more favorability towards company development perspectives and less attention of the regulatory institutions.

Regarding heterogeneity of the stakeholder groups mentioned above and a company's multiple objectives and behavior towards these stakeholders, reputation among national and local authorities, reputation in regulatory institutions, reputation in professional societies, etc. might be singled out as the components of a corporate reputation portfolio.

\subsection{Reputation in Diffused Groups of Stakeholders}

This co-reputation consists of reputations among journalists, community members, special interest and other groups which take interest in an organization when they are concerned about protecting the rights of either the other people (Dowling, 2002): community, minorities, equal employment opportunities, or the environment. The expected benefits of investments to this co-reputation are more favorability towards company performance and development, more support and/or placability during a reputational crisis.

\subsection{Reputation among Rivals}

Considering rivals as one more significant group of stakeholders, reputation among rivals might be categorized as the next type of co-reputation and important part of a corporate reputation portfolio. Reputation among rivals works as a powerful signal to the rivals; it influences their intentions and actions towards the company and plays the role of a barrier for rivals' actions in the marketplace (Fombrum, 1996). Thus, it cannot be disregarded when creating and managing a portfolio of company reputations.

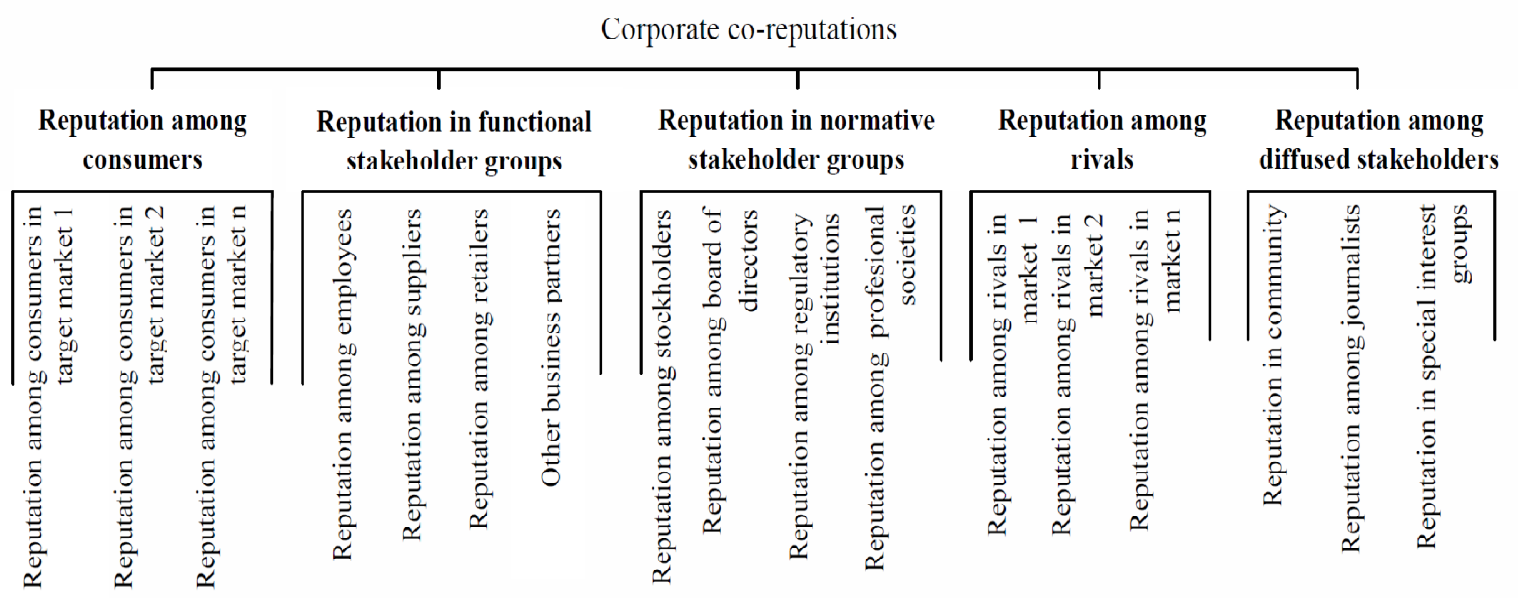

Figure 1. Co-reputations as the components of a corporate reputation portfolio

Source: developed by authors with reference to Dowling (2002).

Acknowledging the equal importance of all the stakeholders and all the co-reputations mentioned (Fig. 1) cannot find any approval in the context of scare corporate resources when there is a need for rational allocation of 
corporate resources for company performance. Therefore, the assessment of the significance of each co-reputation in the context of a corporate vision, mission, and strategic goals, as well as choosing the co-reputations of topmost importance are the essential steps in creating a corporate reputation portfolio. It's on the strategic level that any company should determine whom its reputation is aimed at (which stakeholder groups). Wasting time on "wrong" stakeholders and "wrong" co-reputations can be as bad as making no effort at all (Money and Gardiner, 2005).

\section{Sub-Reputations as the Components of a Corporate Reputation Portfolio}

\subsection{Theoretical Background for Distinguishing Sub-Reputations}

When strategic co-reputations are chosen, the following step in creating a corporate reputation portfolio should be the determination of stakeholder needs and expectations in the context of every co-reputation selected. This is a challenge and a continuous process, since expectations may vary inside a stakeholder group, considering time, locations, and situations.

Generally two types of stakeholder expectations are being discussed in the context of reputation management. The first is a group of rational expectations, and the second is related to moral issues. Neville et al. (2005) point out corporate reputation sets on the basis of instrumental and normative stakeholder expectations. With reference to this approach, at least two specific components of corporate reputation might be distinguished: a reputation based on instrumental (or rational) expectations and a reputation based on normative (or moral) ones.

Referring to Jackson (2004) who claims corporate reputation to be a combination of economic and moral components, two reputational components could be distinguished: economic reputation, related to perceptions and judgments made on the rational basis, and moral reputation, related to perceptions made on the basis of moral norms existing in a particular network.

Kumar (2008) also identifies two distinct parts of corporate reputation, an instrumental and a constitutive one. An instrumental reputation is defined as a reputation for the particular attributes of company offerings (product quality, value, post-sales service, innovativeness, etc.) in the marketplace. A constitutive reputation represents company reputation for its relationship practices (conscientious or not, abusing its bargaining power or not, etc.) and thus relates to normative (moral) expectations.

The necessity for distinguishing economic and normative (moral) components of a corporate reputation portfolio might also be supported by the logic of creating strategies in a marketplace. Baron (1995) and Hemphill (2006) claim for the necessity to have a specific strategy for dealing with nonmarket forces or for integrating two components into a corporate strategy: 1) the market component (or competition one), and 2) the non-market component (or public one). It follows that societal ethical standards and social responsibility as the issues of great importance should be planned in a strategic level and applied to everyday practice of modern business. With the reference to this approach, corporate reputation management as a concurrent part of modern organization should also encompass both corporative (instrumental or economic) and social (normative or moral) practices.

Beyond economic and social expectations towards a company, one more type of a growing pressure on a company from the side of stakeholders is being discussed in the context of seeking corporate sustainability. This is a demand to be an ecologically responsible player as well as an economically competitive and socially responsible company. Hence a company faces a challenge to coordinate and harmonize financial, social, and environmental issues (Orlitzky, Siefel \& Waldman, 2011; Wagner, 2010; Aras and Crowther, 2009; Borland, 2009; Ketola, 2010; Ho and Tyler, 2007) in all its decisions and performances, including reputation management.

Despite frequent considerations of environmental issues as a part of corporate social performance, the differentiation of social and environmental expectations gives some more clarity and advantages in managing a corporate reputation portfolio. Social expectations refer to company performance outcomes towards people inside and outside the organization, and environmental expectations refer to company performance outcomes to a natural environment and planet (Graafland and Smid, 2004).

On the basis of stakeholders' varying expectations discussed above and corporate sustainability concept, at least three components of corporate reputation should be considered, when creating and managing a corporate reputation portfolio: 1) economic-functional reputation, 2) social reputation, and 3) green (environmental) reputation.

These components of corporate reputation, distinguished on the grounds of stakeholder perceptions of company willingness and ability to satisfy different kind of expectations might be called sub-reputations, as the prefix sub- 
has the meaning of part of.

\subsection{Economic-Functional Reputation}

One of the central propositions in this paper is that stakeholders have economic and non-economic interests towards a company. Referring to this approach, corporate reputation refers to a collection of economic and non-economic characteristics (Weigelt and Camerer, 1988; Sanchez and Sotorrio, 2007). Thus, two parts of a corporate reputation portfolio, economic and non-economic, should be distinguished. As working in line with stakeholders' instrumental expectations is the primary goal for any company, an economic-functional reputation is considered as the essential part of a corporate reputation portfolio.

The concept of economic reputation as the stakeholder perception of company's financial results and financial strength has been explored by a number of scholars (Dollinger et al., 1997; De Castro et al., 2004). Yet, this attitude might be reviewed as too constricted in the perspective of seeking sustainable development: stakeholders' economic expectations towards a company are not limited to financial results and encompass more economic responsibilities a company assumes or, is believed, should assume.

Referring to Baumgartner and Ebner (2010), a company has such economic responsibilities as offering an appropriate quality of goods and services, seeking reasonable, not ultimate profits, balancing assets, liabilities, and risks, generating stock value, or giving effective governance. Economic responsibilities also include such fields as innovation and technology, knowledge management, processes. Hus, economic-functional reputation encompasses the perceptions of all the issues mentioned above: the quality of goods and services, profitability, stock value, leadership in innovation, effective governance, etc. Economic-functional reputation might be defined as stakeholders' attitudes and perceptions towards economic and competitive viability of the company-it's abilities to accept economic responsibilities and to meet stakeholders' economic needs.

\subsection{Social Reputation}

Corporate social responsibility has been recently acknowledged as one the most important factors driving corporate reputation (Worcester, 2009; Gallego-Alvarez et al., 2010), and the concept of corporate social responsibility reputation (or social reputation) as a specific type of corporate reputation has been used by number of scholars (Hemphill, 2006; Castaldo et al. 2009; Bebbington et al. 2007; Vonwill and Wreschniok, 2009). Most companies invest in serving stakeholders' normative needs, seeking transparency and generating a common good that overpasses boundaries of the company (Graafland and Smid, 2004) with the intentions to have a better social reputation.

Reputation plays an important role connecting corporate social responsibility with practice (Stuebs and Sun, 2010): the main motive for corporate social responsibility is benefits and expected returns because of a better reputation. This is to say, social reputation plays intermediary role between company's social responsibility practice and stakeholders' reaction towards it. Therefore, social reputation that refers to stakeholder attitudes and perceptions of company abilities and intentions to work in line with social norms and values (Eisenegger, 2009) should be considered as an important component of a non-economic part of a corporate reputation portfolio.

It should be admitted that corporate social responsibility initiatives and actions do not generate benefits per se. The benefits are determined by stakeholder perceptions of company's social obligations - the ones related to employee health, safety and well-being, permanent education, mentoring and training (Baumgartner and Ebner, 2010), community engagement, poverty alleviation, strategic philanthropy, protecting human rights, etc. - and fulfilling the obligations. Corporate social responsibility makes an impact upon company's competitiveness via social reputation: corporate social responsibility initiatives shape and improve social reputation, and social reputation improves competitiveness (Vilanova, et al., 2009).

It should be noted that most theoretical insights and models exploring corporate social responsibility and social reputation issues focus on consumers exclusively and appeal to a presupposition that consumers take an active interest in social responsibilities of a company. In this context, consumers allocate two types of companies: the "good" ones with positive social responsibility reputation and the "bad" ones that disregard social obligations and have a poor social reputation (Castaldo et al., 2009). It is presumed that the "good" companies are awarded by customers with more purchases, and the "bad" ones are punished with lower purchases.

The expression of such a possible "award" for having a positive social reputation varies from a premium price a consumer is willing to pay for product's social characteristics (Auger, Burke, Devinney \& Louviere, 2003; Graafland, 2004) to stronger customers' intentions and decisions to buy a product in retail, to more favorable acceptance of new products (Alexander, 2002; Maignan, 2001; Graafland, 2004). 
Companies having a bad social reputation are punished with lower purchases, or even product boycotts (Marymount University Center of Ethical Concerns, 1999). Referring to Koku, Akhigbe \& springer (1997), 76 percent of consumers prefer not to buy clothes from a retailer which uses sweatshop practice. The number of product boycotts is growing nowadays as the pressure for being socially responsible and media power increase, and a consumer has more choice possibilities in a market.

Despite a common view upon positive returns of investments to a social reputation, some of such statements lack strong empirical evidence (Castaldo et al., 2009). There can be found a much more moderate viewpoint towards the benefits of social reputation. With reference to Carrigan and Attalla (2001) and Castaldo et al. (2009), the perceptions of a company as a socially responsible market player and a good citizen do not necessarily correlate with consumer loyalty and readiness to pay premium prices; they not always are a source of product differentiation and stimulate decisions to buy the product. According to Brown and Dacin (1997), consumer perceptions about company's competency and abilities to produce high quality products (or economic-functional reputation) make a stronger impact on consumer behavior than consumer perceptions of company's social responsibility and keeping social obligations (Castaldo et al., 2009).

Notwithstanding a predominant focus on creating social reputation among customer target groups, corporate social responsibility potential to impact behaviors of other stakeholder groups, employees and investors (Maden et al, 2012; Alniacik et al, 2011), has gain some attention recently. Yet the questions of how the corporate signals of being socially responsible are perceived in these stakeholder groups, and how the perceptions leverage social reputation, and what benefits they generate are still open (Arendt and Brettel, 2010; Smith, 2003; Aqueveque, 2005; Sen, Bhattacharya \& Korschun, 2006; Bhattacharya et al., 2009; Vlachos et al., 2009). Despite the ongoing discussions, the necessity for integrating social responsibility into a corporate strategy and perceiving social reputation as an important part of a corporate reputation portfolio can hardly be denied.

\subsection{Green Reputation}

Despite a common exploration of the concepts of a green product, green consumer, etc., the concept of green reputation is rather a fresh one. It is used fragmentarily while discussing corporate environmental obligations and stakeholder expectations towards company's involvement in environmental issues (Toms, 2002; Dhār and Vine, 2005; Biloslavo and Trnavčevič, 2009; etc.) without any deeper investigation on how green reputation is being created and managed.

The need for distinguishing corporate green reputation (or environmental reputation) as an important part of a corporate reputation portfolio can be supported by an increasing pressure from stakeholders to accept not only economic, but also environmental responsibilities while seeking corporate sustainability (Orlitzky, Siefel \& Waldman, 2011; Babiak and Trendafilova, 2011).

Corporate green reputation might be defined as corporate stakeholders' perceptions, beliefs, and emotional attitudes towards company's environmental responsibilities and practice. A green reputation encompasses a) attitudes and perceptions of company's willingness and abilities to accept environmental responsibilities; $b$ ) perceptions towards company's environmental initiatives and practices implemented; c) emotional attitudes towards company's environmental practice.

The motives for creating eco-friendly strategies, for implementing environmental activities and for building green reputations vary among companies. Haddock-Fraser and Tourelle (2010) claim that corporate intentions for environmental responsibilities depend on company size, stakeholders' pressure, industry, geographic location, and managers' values and believe. The most popular motives for acting in an eco-friendly way are a) seeking to avoid confrontation with regulators and appropriate pieces of legislation, especially when acting in environmentally sensitive industries, b) searching for new niche markets and c) for moral satisfaction (Biloslavo and Trnavčevič, 2009). Environmental practices are also used for corporate branding, for building trustworthiness, seeking favorability and support from external stakeholders (Hillestad et al., 2010). For some companies, strong environmental reputation works as a buffer for softening damage of poor reputation in the area of human rights (Beder, 2002).

The most popular environmental activities vary from recycling and waste management to eco-friendly purchases, to pollution prevention, ecological disaster prevention and recovery, to carbon footprint, to complying with industry environmental norms and standards, to supporting local or global environmental issues and environmental issues of the product, to mention just a few.

The main benefit of having the reputation of a "green company" is a better differentiation of a company, its products, and services among rivals, that might help in making the first contact with stakeholders and supporting 
positive relations with them (Biloslavo and Trnavčevič, 2009). Referring to Tandberg's (2007) study results, more than a half of consumers give priority to products and services of those companies which have eco-friendly reputations, and 80 percent of global workers prefer working for an eco-friendly company.

Despite the fact that the benefits generated by green reputation still lack deeper empirical investigation, corporate signals about being an environmentally responsible player in the market are getting more and more frequent. Corporate environmental reports, that inform stakeholders of a company's environmental programs and initiatives, are one of the most popular instruments for shaping stakeholders' perceptions about a company's willingness to operate in an eco-friendly manner (Mason and Mason, 2012) and developing green reputation. Corporate expenditures for advertising with some reference to environment are increasing rapidly, and green marketing is considered to be one of the fastest growing business segments (Cohen, 2009).

Applying traditional techniques and means for creating a green image and reputation determines the situation when millions are being spent on advertising and on company stretching, coming out with more sustainability reports and green projects and initiatives, and it does not work (Cohen, 2009). Cohen claims, companies need some new ideas, methods, and means when shaping an environmental image and reputation, since the traditional content, channels, and delivery of corporate communication do not meet the brains and hearts of stakeholders or/and do not shape more positive attitudes and behavior towards the company.

Therefore, in the context of managing green reputation, there should be at least four steps emphasized: a) introduction of appropriate environmental standards and norms into a corporate identity as a corporate reputation platform, b) assessment of the expectations towards company's environmental obligations in the groups of multiple stakeholders, c) introduction of proactive environmental initiatives (Haddock-Fraser and Tourelle (2010), d) search for new ways of sending communicational signals to stakeholders about company's obligations to go green.

The benefits that a positive environmental reputation generates among the groups of multiple stakeholders still lack investigation. Therefore, some scholars presume, corporate environmental issues and programs are more about creating strategies for restructuring a portfolio and facing the pressure for corporate governance than about creating reputation strategies (Toms, 2002). Nonetheless, it is admitted that the implemented corporate environmental strategies generate reputational assets through sending signals about corporation's willingness to act in an environment friendly manner.

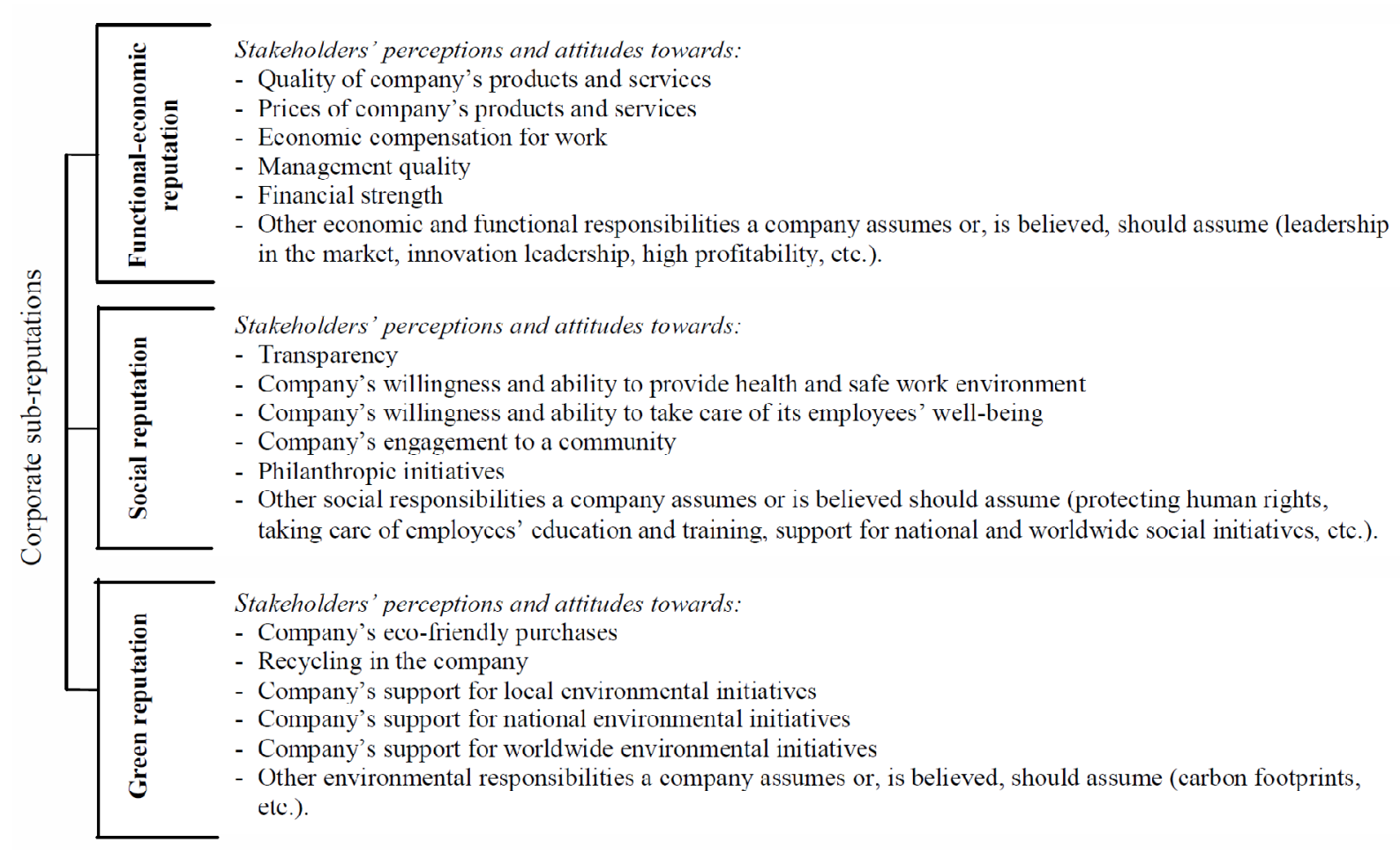

Figure 2. Sub-reputations as the components of a corporate reputation portfolio 
In summary, corporate sub-reputations refer to a) stakeholder perceptions of company's willingness and abilities to work in line with economic, social, and environmental expectations; b) stakeholder perceptions of economic performance in the market and social and environmental initiatives implemented; c) stakeholders' emotional attitudes towards company's economic, social, and environmental performance (Figure 2).

\section{Framework of Integrating Reputational Components into a Corporate Reputation Portfolio}

As co-reputations present diverse perceptions and attitudes towards a company among stakeholder groups, and sub-reputations refer to stakeholder perceptions and attitudes towards company's willingness and abilities to work in line with economic, social, and environmental expectations. The reputational components, discussed above, might be integrated into a matrix of a structural corporate reputation portfolio composition (Fig. 3).

The number of co-reputations as the components of a corporate reputation portfolio is determined by key decision-makers of a company in coherence with a company's mission, vision, and strategic goals. Sub-reputations are treated as the pieces of each co-reputation: economic-functional reputation refers to an instrumental (rational) part of a co-reputation and social and green reputations refer to a normative part.

Expectations towards a company's economic, social and environmental responsibilities in every group of stakeholders of strategic importance should be investigated. The expectations, revealed in the all three fields, should be used as a backbone while shaping perceptions and attitudes towards a company.

Hence, the reputation in target consumer groups consists of a) consumer perceptions and attitudes towards company's willingness and ability to assume functional-economic responsibilities, relevant to target consumers (economic-functional reputation), b) consumer perceptions and attitudes towards company's willingness and ability to assume social responsibilities, relevant to this group (social reputation), and c) consumer perceptions and attitudes towards company's willingness and ability to assume environmental responsibilities, important to this group of stakeholders (green reputation).

\begin{tabular}{|c|c|c|c|c|}
\hline & $\begin{array}{c}\text { Co-reputation } 1 \\
\text { Reputation among } \\
\text { consumers }\end{array}$ & $\begin{array}{c}\text { Co-reputation } 2 \\
\text { Reputation among } \\
\text { employecs }\end{array}$ & $\begin{array}{c}\text { Co-reputation } N \\
\text { Reputation in a } \\
\text { stakcholder group } \mathbf{N}\end{array}$ & $\begin{array}{l}\text { Co-reputation }(N+1) \\
\text { Reputation in a } \\
\text { stakeholder group } \\
(\mathbf{N}+1)\end{array}$ \\
\hline $\begin{array}{l}\text { Sub-reputation } 1 \\
\text { Economic- } \\
\text { functional } \\
\text { reputation }\end{array}$ & $\begin{array}{l}\text { Consumer perceptions } \\
\text { and attitudes towards } \\
\text { company's willingness } \\
\text { and ability to assume } \\
\text { finctional-economic } \\
\text { responsibilties, relevant to } \\
\text { this group of consumers. }\end{array}$ & $\begin{array}{l}\text { Employee perceptions and } \\
\text { attitudes towards company's } \\
\text { willingness and ability to } \\
\text { assume functional-economic } \\
\text { responsibilities, relevant to } \\
\text { employees. }\end{array}$ & $\begin{array}{l}\text { Stakeholders } N \text { perceptions } \\
\text { and attitudes towards } \\
\text { company's willingness and } \\
\text { ability to assume functional- } \\
\text { economic responsibilities, } \\
\text { relevant to a stakeholder } \\
\text { group } \mathrm{N} \text {. }\end{array}$ & $\begin{array}{l}(\mathrm{N}+1) \text { stakeholder } \\
\text { perceptions and attitudes } \\
\text { towards company's } \\
\text { willingness and ability to } \\
\text { assume finctional-economic } \\
\text { responsibilities, relevant to a } \\
\text { stakeholder group }(\mathrm{N}+1)\end{array}$ \\
\hline $\begin{array}{l}\text { Sub-reputation } 2 \\
\text { Social } \\
\text { reputation }\end{array}$ & $\begin{array}{l}\text { Consumer perceptions } \\
\text { and autitudes towards } \\
\text { company's willingness } \\
\text { and ability to assume } \\
\text { social responsibilities, } \\
\text { relevant to this group. }\end{array}$ & $\begin{array}{l}\text { Employec perecptions and } \\
\text { attiludes towards company's } \\
\text { willingness and ability to } \\
\text { assume social } \\
\text { responsibilities, relevant to } \\
\text { employees. }\end{array}$ & $\begin{array}{l}\text { Stakeholders N perceptions } \\
\text { dnd atlitudes towards } \\
\text { company's willingness and } \\
\text { ability to assume social } \\
\text { responsibilities, relevant to } \\
\text { a stakcholder group N. }\end{array}$ & $\begin{array}{l}\text { (N+1) stakeholder } \\
\text { perceptions and altiludes } \\
\text { towards company's } \\
\text { willingness and ability to } \\
\text { assume social } \\
\text { responsibilitics, relevant to a } \\
\text { stakeholder group }(\mathrm{N}+1)\end{array}$ \\
\hline $\begin{array}{l}\text { Sub-reputation } 3 \\
\text { Green } \\
\text { reputation }\end{array}$ & $\begin{array}{l}\text { Cuısume peiveptivis } \\
\text { and attitudes towards } \\
\text { company's willingness } \\
\text { and ability to assume } \\
\text { environmental } \\
\text { responsibilities, relevant } \\
\text { to this group. }\end{array}$ & $\begin{array}{l}\text { Employce pcrceptions and } \\
\text { attitudes towards company's } \\
\text { willingness and ability to } \\
\text { assume cnvironmental } \\
\text { responsibilities, relevant to } \\
\text { emplnyees }\end{array}$ & $\begin{array}{l}\text { Stakcholdcrs N pcrccptions } \\
\text { and attiludes lowards } \\
\text { company's willingness and } \\
\text { ability to assume } \\
\text { environmental } \\
\text { responsihilities, relevant io } \\
\text { a stakeholder group N. }\end{array}$ & $\begin{array}{l}\text { (N।1) stakeloolder } \\
\text { perceptions and attitudes } \\
\text { towards company }{ }^{\circ} \mathrm{s} \\
\text { willingness and ability to } \\
\text { assume environmental } \\
\text { responsibilities, relevant to a } \\
\text { stakeliolder group (N।1) }\end{array}$ \\
\hline
\end{tabular}

Figure 3. A framework for a structural composition of a corporate reputation portfolio

Note: The number of co-reputations is determined by key decision-makers of a company in coherence with company's mission, vision, and strategic goals. Abbreviation $\mathrm{N}$ represents any stakeholder group of strategic importance (suppliers, retailers, community, local authorities, etc.) chosen by key decision-makers in a company. 'Co-reputation N' means reputation in a group of ' $N$ ' stakeholders, which is chosen for systematic reputation management. 
The structure of the other co-reputations-reputation among employees, retailers, business partners, and other stakeholders of strategic importance-is composed on the same logic and includes the three sub-reputations, discussed above.

As stakeholders have diverse expectations, the proportions of sub-reputations in multiple groups of stakeholders vary. In some groups of stakeholders, economic-functional reputation might play a crucial role, while other sub-reputations might be defined as reputations of low importance; and, on the contrary, inside other groups, the reputation based on moral standards might play a dominant role. The weight of each sub-reputation in every co-reputation of strategic importance is set by decision-makers on the basis of stakeholder expectations research, on business strategy, goals, and vision.

The framework of integrating reputational components into a structural composition of a corporate reputation portfolio enables a) the diversification in setting multiple objectives of reputation management, b) the diversification of investments and techniques in shaping reputations, c) the balancing of economic-functional, social, and environmental obligations towards strategic stakeholders, when striving for uniqueness and differentiation in the market, and seeking organizational sustainability.

\section{Conclusions and Future Research Directions}

The presented structural composition of a corporate reputation portfolio has been based on the following presuppositions: a) companies invest in specific types of reputations (selected components of corporate reputation); b) companies invest in managing reputations as a form of intangible assets because of the expected future benefits from strong positive reputations, generated in the marketplace; c) the number and importance of the components of a corporate reputation portfolio are not constant: they are determined by key decision-makers of a company in coherence with company's mission, vision, and strategic goals; d) companies face a challenge to harmonize financial, social, and environmental issues in all its decisions and performances, including reputation management.

The components of a corporate reputation portfolio are brought under two groups: a) group of co-reputations, and b) group of sub-reputations. Co-reputations are distinguished on the basis of heterogeneity of stakeholder characteristics and refer to company's stakeholder-specific reputations, existing at the same time, but being diverse in multiple stakeholder groups. Sub-reputations, as integral components of co-reputations, are distinguished on the basis of instrumental and normative expectations that stakeholders have towards the company and the concept of sustainable development.

The proposed logic for arranging the components of corporate reputation into co-reputations and sub-reputations as well as the framework for integrating the components into a structural composition of a corporate reputation portfolio enable the prioritization of the reputations of strategic importance and diversification of decisions and actions in reputation management, seeking the expected benefits more effectively.

In business practice, the proposed structural composition of a corporate reputation portfolio might be used as a mean of a) diversification in setting multiple objectives of reputation management, regarding heterogeneity of stakeholder characteristics, expectations, and a corporate strategy, b) allocating more and better resources for strategic reputations, and c) selecting multiple means for managing different types of reputations. The reputation portfolio with the proposed structural composition might also be used as a supporting instrument while seeking corporate sustainability.

The conceptual framework presented is based on intersection of the literature in the fields of reputation management, business strategy and corporate sustainability. No empirical research was conducted. Researchers are encouraged to empirically test the proposed structural composition of a corporate reputation portfolio.

\section{References}

Alexander, E. C. (2002). Consumer reactions to unethical service recovery. Journal of Business Ethics, 36, 223-237. http://dx.doi.org/10.1023/A:1014086327876

Alniacik, U., Cigerim, E., Akcin, K., \& Bayram, O. (2011). Independent and joint effects of perceived corporate reputation, affective commitment and job satisfaction on turnover intentions. Procedia Social and Behavioral Sciences, 24, 1177-1189.

Andrikopoulos, A., \& Koronis, E. (2007). Reputation performance: a portfolio selection approach. International Journal of Business Performance Management, 9(4), 406-418.

Aras., G., \& Crowther, D. (2009). Corporate sustainability reporting: a study in disingenuity. Journal of Business Ethics, 87, 279-288. http://dx.doi.org/10.1007/s10551-008-9806-0 
Arendt, S., \& Brettel, M. (2010). Understanding the influence of corporate social responsibility on corporate identity, image and firm performance. Management Decisions, 48(10), 1469-1491. http://dx.doi.org/10.1108/00251741011090289

Aqueveque, C. (2005). Signaling corporate values: consumers' suspicious minds. Corporate Governance, 5(3), 70-81. http://dx.doi.org/10.1108/14720700510604715

Auger, P., Burke, P., Devinney, T. M., \& Louviere, J. J. (2003). What will consumers pay for social product features? Journal of Business Ethics, 42, 281-304. http://dx.doi.org/10.1023/A:1022212816261

Babiak, K., \& Trendafilova, S. (2011). CSR and environmental responsibility: motives and pressures to adopt green management practices. Corporate Social Responsibility and Environmental Management, 18, 11-24. http://dx.doi.org/10.1002/csr.229

Baron, D. P. (1995). Integrated strategy: market and nonmarket components. California Management Review, 37(2), 47-65.

Baumgartner, R. J., \& Ebner, D. (2010). Corporate sustainability strategies: sustainability profiles and maturity levels. Sustainable Development, 18, 76-89. http://dx.doi.org/10.1002/sd.447

Bebbington, J., Carlos, L. C., \& Moneva, J. M. (2008). Corporate social reporting and reputation risk management. Accounting, Auditing \& Accountability Journal, 21(3), 337-361.

Beder, S. (2002). Environmentalists help manage corporate reputation: changing perceptions not behaviour. Ecopolitics, 1(4), 60-72.

Bhattacharya, C. B., Sen, S., \& Korschun, D. (2009). Strengthening stakeholder company relationships through mutually beneficial corporate social responsibility initiatives. Journal of Business Ethics, 85, 257-272. http://dx.doi.org/10.1007/s10551-008-9730-3

Biloslavo, R., \& Trnavcevic, A. (2009). Web sites as tools of communication of a "green" company. Management Decision, 47(7), 1158-1173. http://dx.doi.org/10.1108/00251740910978359

Borland, H. (2009). Conceptualizing global strategic sustainability and corporate transformational change. International Marketing Review, 26(4/5), 554-572. http://dx.doi.org/10.1108/02651330910972039

Brown, T. J., \& Dacin, P. A. (1997). The Company and the Product: Corporate Associations and Consumer Product Responses. Journal of Marketing, 61, 68-84.

Cable, D. M., \& Graham, M. E. (2000). The determinants of job seekers' reputation perceptions. Journal of Organizational Behavior, 21(8), 929-947.

Carrigan, M., \& Attalla, A. (2001). The myth of the ethical consumer - do ethics matter in purchase behaviour? Journal of Consumer Marketing, 18(7), 560-578. http://dx.doi.org/10.1108/07363760110410263

Castaldo, S., Perrini, F., Misani, N., \& Tencati, A. (2009). The Missing Link between Corporate Social Responsibility and Customer Trust: The Case of Fair Trade Products. Journal of Business Ethics, 84, 1-15. $\mathrm{http}: / / \mathrm{dx}$. doi.org/10.1007/s10551-008-9669-4.

Cohen, J. (2009). Getting the stain out of sustainable brands. In J. Klewes \& R. Wreschniok (Eds.), Reputation Capital. Building and maintaining Trust in the 21st Century (pp. 236-248). London: Springer.

Dalton, J., \& Croft, S. (2003). Managing Corporate Reputation: The New Currency. London: Thorogood.

De Castro, G., Saez, P., \& Lopez, J. (2004). The role of corporate reputation in developing relational capital. Journal of Intellectual Capital, 5(4), 575-585. http://dx.doi.org/10.1108/14691930410567022

Dhir, K., \& Vinen, D. (2005). Managing corporate respectability: concept, issues, and policy formulation. Corporate Communications: An International Journal, 10(1), 5-23.

Dollinger, M., Golden, P., \& Saxton, T. (1997). The effect of reputation on the decision to joint-venture. Strategic Management Journal, 18(2), 127-40.

Dowling, G. (2002). Creating Corporate Reputations: Identity, Image, and Performance. New York: Oxford University Press.

Eberl, M., \& Schwaiger, M. (2005). Corporate reputation: disentangling the effects on financial performance. European Journal of Marketing, 39(7/8), 838-854. http://dx.doi.org/10.1108/03090560510601798

Eisenegger, M. (2009). Trust and reputation in the age of globalization. In J. Klewes \& R. Wreschniok (Eds.), Reputation Capital. Building and maintaining Trust in the 21st Century (pp. 11-22). London: Springer. 
Fombrum, Ch. J. (1996). Reputation: realizing value from the corporate image. Boston: Harvard Business School Press.

Gallego-Alvarez, I., Prado-Lorenzo, J. M., Rodriguez-Dominguez, L., \& Garcia-Sanchez, I. M. (2010). Are social and environmental practices a marketing tool? Empirical evidence for the biggest European companies. Management Decision, 48(10), 1440-1455. http://dx.doi.org/10.1108/00251741011090261

Graafland, J. J. (2004). Collusion, reputation damage and interest in code of conduct; the case of Dutch construction company. Business Ethics: A European Review, 2-3(13), 127-142.

Graafland, J. J., \& Smid, H. (2004). Reputation, corporate social responsibility, and market regulation. Tijdschrift voor Economie en Management, 49, 271-308.

Jackson, K. T. (2004). Building reputational capital: strategies for integrity and fair play that improve the bottom line. New York: Oxford University Press.

Haddock-Fraser, J. E., \& Tourelle, M. (2010). Corporate motivations for environmental sustainable development: Exploring the role of consumers in stakeholder engagement. Business Strategy and the Environment, 19, 527-542. http://dx.doi.org/10.1002/bse.663

Hemphill, T. A. (2006). Corporate internal investigations: balancing firm social reputation with board fiduciary responsibility. Corporate Governance, 6(5), 635-642. http://dx.doi.org/10.1108/14720700610706117

Helm, S. (2007). One reputation or many? Comparing stakeholder's perceptions of corporate reputation. Corporate Communications: An International Journal, 12(3), 238-254.

Hillestad, T., Xie, C., \& Haugland, S. A. (2010). Innovative corporate social responsibility: the founder's role in creating a trustworthy corporate brand through "green innovation". Journal of Product \& Brand Management, 19(6), 440-451. http://dx.doi.org/10.1108/10610421011085758

Ho, L. Ch., \& Tyler, M. E. (2007). An empirical analysis of triple bottom-line reporting and its determinants: evidence from the United States and Japan. Journal of International Financial Management and Accounting, 18(2), 124-150.

Ketola, T. (2010). Five leaps to corporate sustainability through a corporate responsibility portfolio matrix. Corporate Social Responsibility and Environmental Management, 17, 320-336.

Koku, P. S., Akhigbe, A., \& Springer, T. M. (1997). The Financial Impacts of Boycotts and Threats of Boycott. Journal of Business Research, 40, 15-20.

Kumar, A. (2008). Some pain, some gain: the role of reputation in governing interfirm relationships. Retrieved July 1, 2010, from http://research3.bus.wisc.edu

Luoma-aho, V. (2007). Reputation formation of innovations. Innovation Journalism, 4(2). Retrieved September 10, 2010, from http://www.innovationjournalism.org/ij4/presentations/vilmaluoma-aho.pdf

Maden, C., Arikan, E., Telci, E. E., \& Kantur, D. (2012). Linking Corporate Social Responsibility to Corporate Reputation: A Study on Understanding Behavioral Consequences. Procedia Social and Behavioral Sciences, $58,655-664$.

Maignan, I. (2001). Consumers' perceptions of corporate social responsibilities: a cross-cultural comparison. Journal of Business Ethics, 30, 57-72. http://dx.doi.org/10.1023/A:1006433928640

Marymount University Center of Ethical Concerns. (1999). The Consumers and Sweatshops. Retrieved September 10, 2012, from http://connect.marymount.edu/news/garmentstudy/overview.html

Mason, M., \& Mason, R. D. (2012). Communicating a Green Corporate Perspective: Ideological Persuasion in the Corporate Environmental Report. Journal of Business and Technical Communication, 26(4), 479-506. http://dx.doi.org/10.1177/1050651912448872

Money, K., \& Gardiner, L. (2005). Reputational management: ignore at your own peril. Handbook of Business Strategy, 6(1), 43-46. http://dx.doi.org/10.1108/08944310510556946

Neville, B. A., Bell, S. J., \& Menguc, B. (2005). Corporate reputation, stakeholders and the social performance-financial performance relationship. European Journal of Marketing, 39(9/10), 1184-1198.

Orlitzky, M., Siegel, D. C., \& Waldman, D. A. (2011). Strategic corporate social responsibility and environmental sustainability. Business \& Society, 50(1), 6-27.

Rutkauskas, A. V., Lapinskaite-Vvohlfahrt, I., \& Stasytyte, V. (2011). Marketing Portfolio Management in a 
Spectrum of Marketing Assets Interaction to Maximize Holder's Utility. Inzinerine Ekonomika-Engineering Economics, 22(5), 485-493.

Sanchez, J. L. F., \& Sotorrio, L. L. (2007). The creation of value through corporate reputation. Journal of Business Ethics, 79, 335-346. http://dx.doi.org/10.1007/s10551-006-9285-0

Sen, S., Bhattacharya, C. B., \& Korschun, D. (2006). The role of corporate social responsibility in strengthening multiple stakeholder relationships: a field of experiment. Journal of the Academy of Marketing Science, 34, 158-166. http://dx.doi.org/10.1177/0092070305284978

Smaiziene, I., \& Jucevicius, R. (2010). Facing multidimensional nature of corporate reputation: challenges for managing reputation. Socialiniai Mokslai (Social Sciences), 3(69), 48-56.

Smith, N. C. (2003). Corporate social responsibility: whether or how? California Management Review, 45, 52-76.

Stuebs, M., \& Sun, L. (2010). Business reputation and labor efficiency, productivity, and cost. Journal of Business Ethics, 96, 265-283.

Tandberg. (2007). Corporate environmental behavior and the impact on brand values. Retrieved October 10, 2012, http://www.ivci.com/pdf/corporate-environmental-behaviour-and-the-impact-on-brand-values.pdf

Toms, J. S. (2002). Firm resources, quality signals and the determinants of corporate environmental reputation: some of UK evidence. British Accounting Review, 34, 357-582. http://dx.doi.org/10.2139/ssrn.1714030

Vilanova, M., Lozano, J., \& Arenas, D. (2009). Exploring the nature of the relationship between CSR and competitiveness. Journal of Business Ethics, 87, 57-69. http://dx.doi.org/10.1007/s10551-008-9812-2

Vlachos, P. A., Tsamakos, A., Vrechopoulos, A. P., \& Avramidis, P. K. (2009). Corporate social responsibility: attributions, loyalty, and the mediating role of trust. Journal of the Academy of Marketing Science, 37, 170-180.

Vonwill, M., \& Wreschniok, R. (2009). The CSR myth: true beauty comes from within. In J. Klewes \& R. Wreschniok (Eds.), Reputation Capital. Building and maintaining Trust in the 21st Century (pp. 83-99). London: Springer.

Walker, K. (2010). A systematic review of the corporate reputation literature: definition, measurement, and theory. Corporate Reputation Review, 12, 357-387. http://dx.doi.org/10.1057/crr.2009.26

Wagner, M. (2010). The role of corporate sustainability performance for economic performance: A firm-level analysis of moderation effects. Ecological Economics, 69, 1553-1560.

Weigelt, K., \& Camerer, C. (1988). Reputation and Corporate Strategy: A Review of Recent Theory and Applications. Strategic Management Journal, 9(5), 443-454. http://dx.doi.org/10.1002/smj.4250090505

Worcester, T. (2009). Reflections on corporate reputation. Management Decisions, 47(4), 573-589. http://dx.doi.org/10.1108/00251740910959422

\section{Copyrights}

Copyright for this article is retained by the author(s), with first publication rights granted to the journal.

This is an open-access article distributed under the terms and conditions of the Creative Commons Attribution license (http://creativecommons.org/licenses/by/3.0/). 